РОЛЬ ІННОВАЦІЙНИХ ТЕХНОЛОГІЙ У ВИВЧЕННI ІНОЗЕМНОÏ МОВИ

\title{
THE ROLE OF INNOVATIVE TECHNOLOGIES IN LEARNING A FOREIGN LANGUAGE
}

у статmі розкрито можливість впровадження, освоєння і здійснення інноваційних технологій в освітньому процесі. Ставиться завдання з'ясувати, через що виникають інноваціі, якими вони бувають; розглядаються історичний розвиток інноваційного процесу, його сенс і результат. Взагалі інноваційний процес - це цілеспрямований процес зі створення, освоєння, використання та поширення сучасних ідей, які відповідають певним критеріям. У розумінні сенсу інноваційного процесу лежать дві важливі проблеми педагогіки: проблема впровадження психолого-педагогічних досягнень у практику і проблема вивчення педагогічного досвіду. Результатом інноваційного прочесу є зміни, які утворюються і в теорії, і практиці.

Нині інноваційна педагогічна діяльність $\epsilon$ одним із важливих компонентів освітньої діяльності в усіх навчальних закладах. Вона як створює конкурентність того чи іншого навчального закладу в області освітніх послуг, так і визначає профресійне зростання педагога, його творчий пошук і сприяє особистісному зростанню вихованців. Застосування нововведень у різних умовах залежить від кваліфікації вчителів, від того, наскільки навчені школярі і який спосіб життя вони ведуть.

Нововведення, або інновації, характерні для будь-якої профресійної діяльності людини, i тому природно стають предметом вивчення, аналізу та впровадження. Інновації самі по собі не виникають, вони є результатом наукових пошуків, передового педагогічного досвіду окремих вчителів і цілих колективів. Цей процес не може бути стихійним, він потребує управління.

При всьому різноманітті технологій навчання: саморозвитку, комп'ютерних, проблемних, модульних і інших - реалізація провідних педагогічних фуннкцій залишається за педагогом. Це вимагає від нього спеціальноі психолого-педагогічної підготовки, оскільки в профресійній діяльності вчителя реалізуються не тільки спеціальні, предметні знання, а й сучасні знання в галузі педагогіки $і$ психології, технології навчання і виховання. Ключові слова: інновації, технології, іноземна мова, інноваційні процеси, методика викладання, електронні ресурси, зміст навчальної програми, нововведення.
The article reveals the possibility of introduction, development and implementation of innovative technologies in the educational process. The task is to find out why innovations arise; what they are; the historical development of the innovation process, its meaning and result are considered. In general, the innovation process is a purposeful process of creating, mastering, using and disseminating modern ideas that meet certain criteria. Understanding the meaning of the innovation process are two important problems of pedagogy: the problem of implementing psychological and pedagogical achievements in practice and the problem of studying pedagogical experience. The result of the innovation process are changes that are formed in both theory and practice.

Today, innovative pedagogical activity is one of the important components of educational activity in all educational institutions. It both creates the competitiveness of an educational institution in the field of educational services, and determines the professional growth of the teacher, his creative search and contributes to the personal growth of students. The application of innovations in different conditions depends on the qualifications of teachers, on how well trained students are, and what way of life they lead. Novations, or innovations, are characteristic of any professional activity of a person, and therefore naturally become the subject of study, analysis and implementation. Innovations do not arise by themselves, they are the result of scientific research, advanced pedagogical experience of individual teachers and entire teams. This process cannot be spontaneous, it needs management.

With all the variety of learning technologies: selfdevelopment, computer, problem, modular and others - the implementation of leading pedagogical functions is left to the teacher. This requires from him special psychological and pedagogical training, as in the professional activities of teachers are implemented not only special, subject knowledge, but also modern knowledge in the field of pedagogy and psychology, technology of teaching and education.

Key words: innovations, technologies, foreign language, innovative processes, teaching methods, electronic resources, curriculum content, novations.
Одеського національного

економічного університету
Постановка проблеми в загальному вигляді. На жаль, реальність така, що, незважаючи на прекрасне опрацювання багатьох освітніх напрямів, реальна освітня практика мало їх приймає. Інновації потрібні для підвищення ефективності освітнього процесу і його результатів. Вирішальну роль у процесі інновацій відіграє викладач, який повинен бути творчим, зацікавленим в інноваціях, який не тільки приймає теоретичні знання, але також шукає нові методи навчання, оновлює зміст освіти тощо.
Аналіз останніх досліджень і публікацій. Спираючись на літературні джерела, ми так само можемо сказати, що інноваційні процеси в освіті виникали в різні історичні періоди і визначали його розвиток. Особливо поширилися вони наприкінці XIX - початку XX століть. Ці зміни характеризувалися новими підходами до навчання і виховання. У цей час наука переживала сильну криза, яка стосувалася уявлень про людину і суспільство, природу, пізнання [2]. Таким чином, інноваційний процес полягає у фрормуванні та розвитку змісту, 
а також в організації нового. У нього входить сукупність процедур і засобів, за допомогою яких відкриття, отримане в науці, або введення стає результатом інновації.

Мета статті - спонукати викладачів глибоко замислитись про можливості поліпшення навчання завдяки інноваційним методам.

Виклад основного матеріалу. У зв'язку зі змінами в соціальному житті прогрес у науці і культурі, нові потреби в педагогічній діяльності привели до змін у системі освіти. Одним із можливих шляхів подальшого розвитку цієї галузі є інновації [1].

Інновації - це зміна або нововведення, яке передбачає введення чого-небудь нового [2] Ці зміни відбуваються в будь-якій професії людини. Інновації відбуваються в результаті наукових пошуків, високого педагогічного досвіду і цілого колективу. У діяльності педагога інновації проявляються 3 введенням нових цілей освіти; в організації спільної діяльності викладача та студента; розробляються нові форми і методи навчання. У всьому цьому процесі викладачі відіграють дуже важливу роль, бо вони і $є$ учасниками цього процесу. 3 введенням у навчально-виховний процес сучасних технологій викладач в аудиторії дедалі більше виконує фрункцію консультанта і порадника.

Найбільш поширені такі інновації в навчанні:

1) створення профрільних аудиторій;

2) ігрових методик;

3) комп'ютерних класів;

4) поява інтерактивних дошок;

5) дистанційне навчання (участь у конореренціях, семінарах, олімпіадах);

6) створюються мережеві структури;

7) тьюторство;

8) електронні підручники.

Спираючись на літературні джерела, ми також можемо сказати, що саме інновації підвищують ефективність і якість освіти, показуючи тим самим результат передового педагогічного досвіду, а також наукових пошуків.

Як правило, інновації виникають у результаті спроб вирішити традиційну проблему в новий спосіб, у результаті тривалого процесу накопичення і осмислення фрактів, коли і народжується нова якість, яка несе новаторський зміст. Більшість сучасних інновацій знаходяться в спадкоємному зв'язку з історичним досвідом і мають аналоги в минулому. Це дає підставу стверджувати, що інноваційний процес - це мотивована, цілеспрямований і свідомий процес зі створення, освоєння, використання та поширення сучасних (або осучаснених) ідей (теорій, методик, технологій і т.п.), які актуальні й адаптовані для цих умов і які відповідають певним критеріям. Він спрямований на якісне поліпшення системи, в яку вноситься нововведення, і передбачає стимулювання його учасників і зміну їхніх поглядів із позиції нововведення.

В основі інноваційних освітніх процесів лежать дві найважливіші проблеми педагогіки:
- проблема вивчення педагогічного досвіду;

- проблема доведення до практики досягнень психолого-педагогічної науки.

Отже, предмет інноватики, зміст і механізми інноваційних процесів мають лежати в площині об'єднання двох взаємопов'язаних процесів, що розглядаються до теперішнього часу поки ізольовано, тобто результатом інноваційних процесів має бути використання нововведень, як теоретичних, так і практичних, так само і таких, які утворюються на стику теорії та практики. Усе це підкреслює важливість управлінської діяльності зі створення, освоєння і використання педагогічних нововведень. Отже, викладач може виступати як учасник, розробник, дослідник, користувач і пропагандист нових педагогічних технологій, теорій, концепцій. Управління цим процесом забезпечує цілеспрямований відбір, оцінку та застосування у своїй діяльності досвіду колег або пропонованих наукою нових ідей, методик.

Необхідність в інноваційній спрямованості педагогічної діяльності в сучасних умовах розвитку суспільства, культури і освіти визначається низкою обставин.

По-перше, соціально-економічні перетворення, що відбуваються, зумовили необхідність докорінного оновлення системи освіти, методології і технології організації освітнього процесу в освітніх установах різного типу. Інноваційна спрямованість діяльності викладача, що включає в себе створення, освоєння і використання педагогічних нововведень, виступає засобом оновлення освітньої політики [3, с. 149-155].

По-друге, посилення гуманітаризації змісту освіти, безперервна зміна обсягу, складу навчальних дисциплін вимагають постійного пошуку нових організаційних форм, технологій навчання.

По-третє, зміна характеру відносин викладача до самого фракту освоєння і застосування педагогічних нововведень.

По-четверте, входження вищих навчальних закладів у ринкові відносини, в тому числі і недержавні, створює реальну ситуацію їх конкурентоспроможності.

Результатом інноваційних процесів в освіті $€$ використання нововведень, як теоретичних, так і практичних, а також тих, які утворюються на стику теорії і практики. Причому інновація в системі освіти передбачає введення нового в цілі освіти, розробку нового змісту, нових методів і фрорм навчання і виховання, впровадження і поширення вже існуючих педагогічних систем, розробку нових технологій управління школою, ї̈ розвиток, школу як експериментальний майданчик, ситуацію, коли школа має принципово нову освітню орієнтацію і здійснює оновлення освіти і виховання, які мають системний характер, який стосується мети, зміст, методи, фрорми та інші компоненти системи освіти. В основі їх розвитку перебувають дві групи чинників: 
а) об'єктивні чинники - створення умов, що стимулюють розвиток інноваційної діяльності та забезпечують прийняття її результатів;

б) суб'єктивні фрактори пов'язані із суб'єктом інноваційного процесу, його готовністю до інноваційної діяльності. Суб'єктами інноваційних процесів виступають вчені-педагоги, вчителі та інші працівники сорери освіти, чия діяльність має інноваційну спрямованість.

П.І. Підкосістий виділяє такі нововведення:

1) технологічні;

2) організаційні;

3) методичні;

4) економічні;

5) управлінські;

6) соціальні;

7) юридичні [1].

Технологічні інновації - це нові способи виготовлення продуктів, нові технології їх виробництва. Ці інновації зачіпають різні технічні засоби і обладнання, які використовуються в навчанні. 3 появою інформаційних технологій та програмного забезпечення відкрилися нові можливості. Оскільки комп'ютерні технології швидко діють, мають величезну кількість пам'яті, вони представляють собою нові засоби навчання. Ці технології створюють індивідуальні підходи у викладанні навчанні, дозволяють реалізовувати ідеї проблемного навчання.

Організаційні інновації - це зміни, які стосуються освоєння нових форм і методів організації праці, способів роботи в класах, шкільних і позашкільних колективах.

Методичні інновації - це нововведення, які застосовуються в галузі викладання і навчання, методики навчання і виховання. Ці інновації стосуються процесу викладання природничо-наукових і гуманітарних дисциплін від дошкільного виховання до вищої освіти.

Економічні інновації - це нововведення, які охоплюють фрінансові, бухгалтерські області, а також оцінку результатів діяльності в освіті. Вони впливають на роботу всієї системи освіти, яка надає населенню платні освітні послуги.

Управлінські інновації - це зміни в структурі, методах управління організаціями, вони орієнтовані на заміну елементів системи управління, яка має прискорити, полегшити або поліпшити вирішення поставлених завдань.

Соціальні інновації - це зміни, які проявляються в системі професійної підготовки і підвищення кваліфрікації працівників, щодо підвищення рівня освіти, системи заохочення і оцінки результатів праці, профресійної підготовки молоді, культури, формуванні корисних навичок і звичок, усунення негативних явищ у житті суспільства, досягненні більш високого рівня вихованості.

І останній вид інновацій - це юридичні, до яких зараховують нові і змінені закони, що визначають і регулюють усі види освітніх установ [1].
На вдосконалення науково-методичного супроводу впливають зміни у вимогах до професійних та особистих якостей сучасного педагога, оновлення цілей освітнього процесу, поява нових засобів, способів, технологій навчання.

Втрачають актуальність традиційні уявлення про педагогічну діяльність як про діяльність, яка здійснюється відповідно до норм у повторюваних педагогічних ситуаціях. Праця вчителя дедалі більшою мірою розглядається як активна участь в інноваційних процесах в освітній установі, вміння педагога поглянути по-новому на ті чи інші ситуації, що виникають під час взаємодії всіх учасників освітнього процесу. 3 огляду на це діяльність педагога стає ще більш багатофункціональною. Педагог активно включається в здійснення різноманітних видів діяльності: створення і впровадження освітніх програм, розробка навчальних засобів, супровід і консультування учнів, участь у розробці програми розвитку освітньої установи, проведення дослідницької діяльності, здійснення методичної роботи, оцінка та комплексна самооцінка результатів освіти, організація взаємодії із зовнішнім середовищем школи. Для якісної та еорективної участі в різних видах діяльності конкретного педагога стає необхідним додатковий науковометодичний супровід.

Зазначені вище визначає складність супроводу, яке має бути оптимальним для внутрішніх і зовнішніх умов роботи педагога, що наявні і що виникають, передбачити майбутні зміни, розробляти і освоювати інноваційні способи реагування на них.

У сучасних умовах педагогу важливо вміти поєднувати адаптивне і інноваційне реагування на мінливу ситуацію в процесах освіти. Адаптивне реагування - прагнення забезпечити відповідність діяльності, заснованої на відпрацьованій системі роботи, сучасним змінам в освіті. Такий тип реагування спрямований на зниження ризику невдачі. Його реалізація виправдана в тих випадках, коли нова ситуація діяльності може виявитися тимчасовою і може різко змінитися, або коли її ефективність ще не зовсім доведені на практиці.

Висновки. 3 усього вищесказаного можна зробити висновок, що саме інновації в результаті наукових пошуків і передового педагогічного досвіду є найкращим засобом підвищення ефективності освіти.

\section{БІБЛІОГРАФИЧНИЙ СПИСОК:}

1. Пидкасистый П.И. Педагогика: учебное пособие для вузов / ответственный редактор П.И. Пидкасистый. 2-е изд. Москва : Издательство Юрайт, 2011. 502 с. URL: https://urait.ru/bcode/339140 (дата обращения: 07.06.2021).

2. Сластенин В.А. и др. Педагогика : Учеб. пособие для студ. высш. пед. учеб. заведений / Под ред. В.А. Сластенина. Москва : Издательский центр «Академия», 2002. 576 с.

3. Лавлинская Л.И. Творческая активность - одна из основ инновационной направленности личности. Роль воспитательной работы в формировании научно-инновационного мировоззрения будущих специалистов : сб. материалов науч.-практ. конф. Воронеж : ВГМА, 2008. С. 149-155. 